\title{
CONTRIBUTION TO THE GENUS USNEA (PARMELIACEAE) IN SLOVAKIA: USNEA GLABRESCENS
}

\author{
Miloš LUKÁČ ${ }^{1,2}$
}

\begin{abstract}
Usnea glabrescens has been reported to be a re-found species after almost 24 years. We found this lichen in the Bielovodská dolina Valley, Tatry Mts. in 2008. The locality is situated in Tatra National Park near the borderline with Poland. Morphology and medullary chemistry of the specimen were typical for the species. Usnea glabrescens grew in a moderately open and humid mixed forest on the bark of Alnus incana.
\end{abstract}

Key words: rounded soralia, stictic acid group, Tatry Mts., Usnea.

\section{Izvleček}

Poročamo o ponovnem odkritju vrste Usnea glabrescens po skoraj 24 letih. Našli smo jo leta 2008 v dolini Bielovodská dolina, v gorovju Tatre. Rastišče je znotraj Nacionalnega parka Tatra v bližini državne meje s Poljsko. Morfologija in medularni kemizem primerka sta značilna za vrsto Usnea glabrescens. Lišaj je uspeval v zmerno odprtem in vlažnem gozdu na lubju sive jelše (Alnus incana).

Ključne besede: zaokroženi soraliji, stictic acid group, gorovje Tatre, Usnea.

\section{INTRODUCTION}

The genus Usnea requires a substantial revision in Slovakia. Occurrence of 34 taxa of this genus was reported in Slovakia (Pišút et al. 1998, Lackovičová 2003). However, it seems that even this amount deviates from reality. Some names of the species are synonyms of others (Randlane et al. 2009). The profound morphological variation of the genus can be a reason for the large number of synonyms. This is probably due to differences in environmental conditions, which are known to play an important role for many fruticose lichens (Holien 1989, Clerc 1998, 2004, Lukáč 2009). Therefore, determination of the genus Usnea is a rather complicated task in most instances. The knowledge of occurrence of the genus Usnea is documented best in the Tatry
Mts. Lisická (2005) revised the species occurrence within the national park. Some species are common (U. filipendula, U. subfloridana, U. rigi$d a$ ), while others are very rare. The authors analyzed only few collected samples (Usnea articulata, $U$. ceratina, $U$. chaetophora, $U$. fulvoreagens, $U$. substerilis). Nine species of the genus Usnea have been considered extinct in Slovakia: Usnea articulata, $U$. cavernosa, U. ceratina, U. fulvoreagens, U. glabrata, U. glabrescens, U. longissima, U. rubicunda and $U$. scabrata (Pišút et al. 1998, Lisická 2005), but $U$. glabrata was recently re-discovered in the Muránska Planina National Park (Guttová \& Palice 2004).

The aim of this study is to revise the occurrence of Usnea glabrescens in Slovakia. The paper broadens the knowledge about the species in the country.

\footnotetext{
${ }^{1}$ Department of Chemical Theory of Drugs, Faculty of Pharmacy, Comenius University, Kalinčiakova 8, SK-832 32 Bratislava; e-mail: lukac@fpharm.uniba.sk

${ }^{2}$ NMR laboratory, Faculty of Pharmacy, Comenius University, Odbojárov 10, 83232 Bratislava, Slovakia
} 


\section{MATERIAL AND METHODS}

The specimen was collected in Bielovodská dolina Valley, Tatry Mts. $\left(20^{\circ} 06^{\prime} 05^{\prime \prime} \mathrm{E}, 4^{\circ} 13^{\prime} 10^{\prime \prime} \mathrm{N}\right.$; altitude 1100 m a.s.l.) on August 30, 2008 (Figure 1). The WGS-84 system was used for determination of geographical position in the locality. The collected sample was identified according to the Key to European Usnea species (Randlane et al. 2009) and it was confirmed according to other literatures (Clerc 1987a, Halonen et al. 1998, Halonen et al. 1999, Matteucci et al. 2006). Thickness of the cortex, medulla and central axis were measured using the method described in the literature (Clerc 1987b). The ratio of the width of the cortex, the medulla and the central axis, is given as a percentage of the radius of the cortex and the medulla, and as a percentage of the diameter in relation to the axis (C/M/A). The studied specimen was subjected to color reagent tests with $p$-phenylenediamine (PD) and thin-layer chromatography, i.e. according to the standard method described by Culberson $(1972,1974)$ and Culberson \& Johnson (1982). The control lichen substances atranorin and norstictic acid were obtained by extracting a fragment of Lobaria pulmonaria (norstictic acid) and Evernia prunastri (atranorin). Extraction of the lichen compounds from the samples was carried out according to Lukáč and Onderka (2006). UV rays were used on detection of phenolic compounds. 2-hydroxybenzaldehydes (constictic acid, norstictic acid, stictic acid) were visualized by a 2 \% solution of 3-aminophenol in ethanol (Lukáč \& Onderka 2009). The specimen is preserved in the author's private collection.

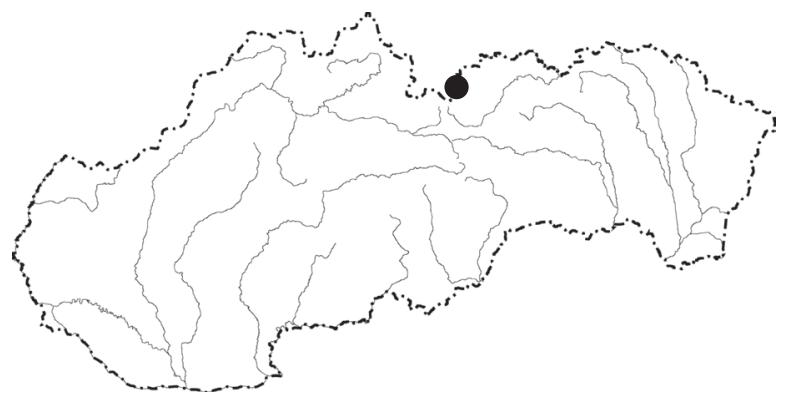

Figure 1: Locality of investigated U. glabescens in Slovakia. Slika 1: Lokacija vrste U. glabescens na Slovaškem.

\section{RESULTS AND DISCUSSION}

The collected sample of $U$. glabrescens (Nyl. ex Vain.) Vain. has a subpendent, $60 \mathrm{~mm}$ long thal- lus. Its color is grey-green. The main branches are from reddish brown to dark brown. The base is distinctly blackened (Figure 2). Annular cracks are present, with white medullary rings. Branching is isotomic-dichotomous. Cortex is relatively thick, $10-14 \%$. Medulla is relatively thin, 15-22\%. Central axis is relatively thick, 38-44 \%. Papillae are low, abundant on main branches (Figure 2 - small picture in left corner). Fibrils are sparse. Soralia are usually widely spaced, even to slightly excavate, distinctively rounded, locally irregular in shape. They are without isidia (Figure 2 - red arrows). Thallus contains usnic acid, stictic acid, norstictic acid and constictic acids. The morphology and chemistry of the sample is typical for this species (see e.g. Halonen et al. 1999). The specimen grew in a moderately open and humid mixed forest. The locality was situated near a stream. The dominant tree species in the forest crop were Picea abies, Alnus incana and Salix sp., while Spruce was dominating the composition of the tree stand. The specimen was growing on the bark of Alnus incana. U. glabrescens grew together with $U$. filipendula and one unidentified specimen. It resembles $U$. diplotypus but some morphological signs and the medullary chemistry are different (for description of $U$. diplotypus, see e.g. Halonen et al. 1999). The differences are as follows: central axis is yellow to brown colored, medulla is compact, branches are tapering, soralia are enlarged and medulla contains norstictic acid and one undefined compound, which can be consalazinic acid or constictic acid beside salazinic acid.

$U$. glabrescens seems to be a relatively common species in Europe, especially in northern Europe (Halonen et al. 1999, Tõrra \& Randlane 2007). It has been previously reported from Slovakia and neighbouring countries (Randlane et al. 2009) but it has not been observed in Slovakia for about 24 years. It was collected last time on August 15, 1984 in the Javorinka Valley, Tatry Mts. (Lisická 2005). U. glabrescens was also reported from other mountains e.g. Veporské Vrchy Mts. (Pišút 1959) or Slanské Vrchy Mts. (Pišút \& Liška 1985). Years of its disappearance caused the species to be considered as extinct in Slovakia; however, the specimen collected in the Bielovodská dolina Valley refutes the supposition of its extinction. U. glabrescens is very rare in Slovakia. The species of the genus Usnea were investigated from 105 localities in Central and East Slovakia, but only one specimen was determined as $U$. glabrescens. 


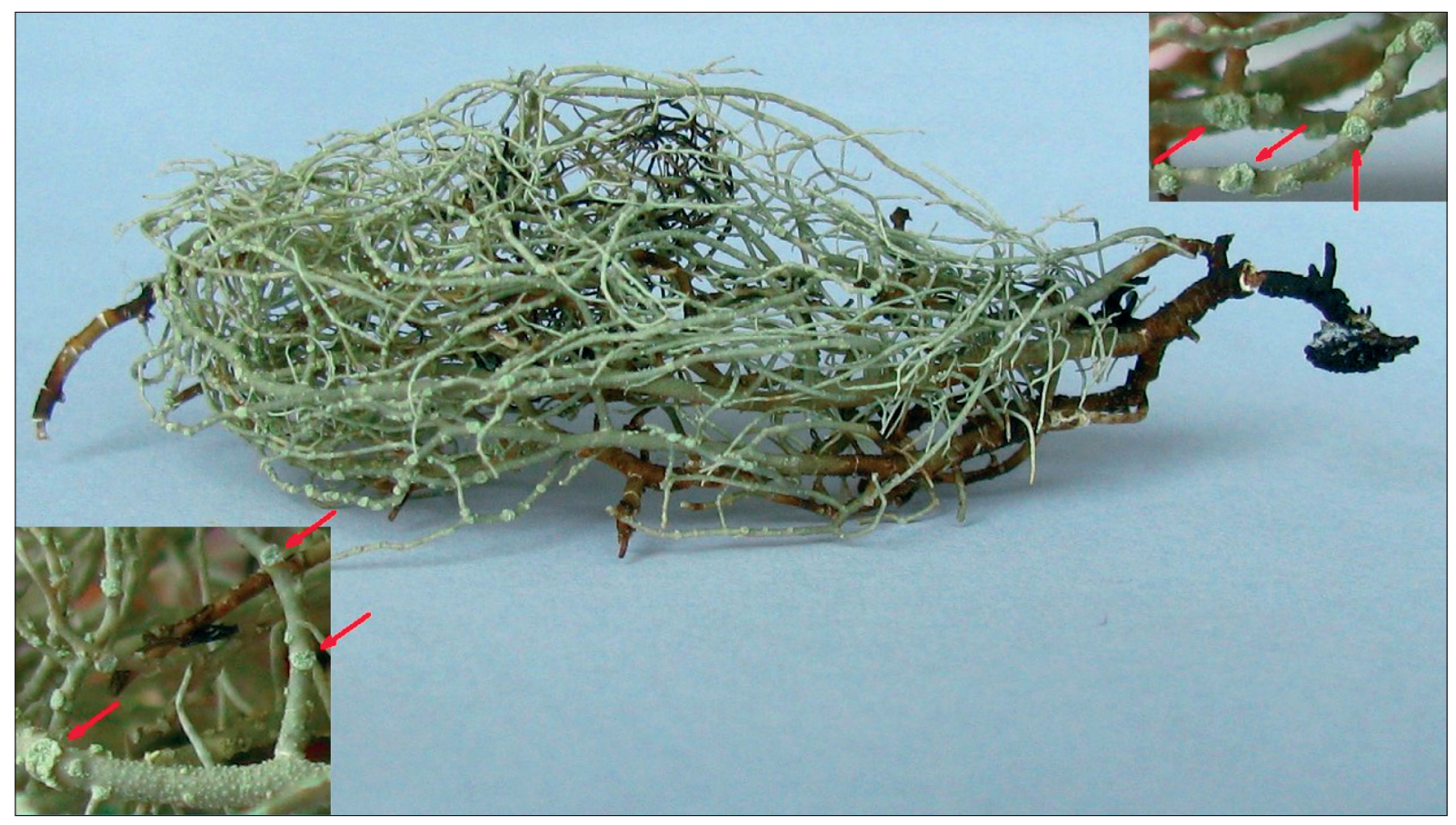

Figure 2: Thallus of collected U. glabrescens. Red arrows show soralia.

Slika 2: Steljka nabranega primerka U. glabrescens. Rdeča puščica nakazuje soralije.

\section{ACKNOWLEDGEMENTS}

I wish to thank Anna Guttová and Martin Mrva for useful comments, and Milan Onderka for correcting the English of the manuscript. This work was supported by Grants: VEGA 1/0164/08.

\section{REFERENCES}

Clerc, P. 1987a: On the morphology of soralia in the genus Usnea. Bibliotheca Lichenologica 25: 99-102.

Clerc, P. 1987b Systematics of the Usnea fragilescens aggregate and its distribution in Scandinavia Nordic Journal of Botany 7: 447-495.

Clerc, P. 1998: Species concepts in the genus Usnea (lichenizead Ascomycetes). Lichenologist 30: 321-340.

Clerc, P. 2004: Notes on the genus Usnea Adanson. II. Bibliotheca Lichenologica 88: 79-90.

Culberson, C.F. 1972: Improved conditions and new data for the identification of lichen product by a standardized thin-layer chromatographic method. Journal of Chromatography 72: 113-125.
Culberson, C.F. 1974: Conditions for the use of Merck silica gel 60 F254 plate in the standardized thin-layer chromatographic technique for lichen products. Journal of Chromatography 97: 107-108.

Culberson, C.F. \& Johnson A. 1982: Substitution of methyl tert.-butyl ether for diethyl ether in the standardized thin layer chromatographic method for lichen products. Journal of Chromatography 238: 483-487.

Guttová, A. \& Palice, Z. 2004: Lichens of National Park Muránska planina III - Cigánka, Reussia, Suppl. 1: 11-47.

Halonen, P., Clerc, P., Brodo, I.M. \& Wulff, K. 1998: Synopsis of the Genus Usnea (Lichenized Ascomycetes) in British Columbia, Canada. Bryologist 101: 36-60.

Halonen, P., Myllys, L., Ahti, T. \& Petrova, O.V. 1999: The lichen genus Usnea in East Fennoscandia. III. The shrubby species. Annales Botanici Fennici 36: 235-256.

Holien, H. 1989: The genus Bryoria sect. Implexae in Norway. Lichenologist 21: 243-258.

Lackovičová, A. 2003: Súhrn doplnkov k zoznamu a bibliografii lišajníkov Slovenska (Summary of contributions on checklist and bibli- 
ography of lichens of Slovakia). Bulletin Slovenskej botanickej spoločnost 25: 17-29.

Lisická, E. 2005: The Lichens of the Tatry Mountains. VEDA, Bratislava, 439 pp.

Lukáč M. 2009: Occurrence and chemical diversity of the genus Bryoria in the Sučí Potok Valley, Veporské Vrchy Mountains (Central Slovakia). Central European Journal of Biology 4: 417-421.

Lukáč, M. \& Onderka, M. 2006: Application of DDQ (2,3 - dichloro - 5,6 - dicyanobenzoquinone) in detection of lichen acids. Acta Facultatis Pharmaceuticae Universitatis Comenianae 56: 160-166.

Lukáč, M. \& Onderka, M. 2009: Substitution of $p$-phenylenediamine by aminophenols in TLC detection of lichen compounds with aldehyde group. Acta Facultatis Pharmaceuticae Universitatis Comenianae 56: 112-118.

Matteucci, E., Munzi, S. \& Potenza, G. 2006: Usnea workshop. Notiziario della Società Lichenologica Italiana 19: 129-137.
Pišút, I. 1959: Nachträge zur Kenntnis der Flechten der Slowakei. (Contribution to knowledge of lichens in Slovakia) Zborník Slovenského národného Múzea, Prírodné Vedy 5: 120-123.

Pišút, I. \& Liška, J. 1985: Lišajníky Slanských vrchov. (Lichens in Slanské vrchy Mts.) Zborník Slovenského národného Múzea, Prírodné Vedy 31: 27-57.

Pišút, I., Guttová, A., Lackovičová, A. \& Lisická, E. 1998: Lichen-forming fungi (Lichens), pp 229-295. In: Marhold K. \& Hindák F. (eds), Checklist of non-vascular and vascular plants of Slovakia. VEDA, Bratislava.

Randlane, T., Tõrra, T., Saag, A. \& Saag, L. 2009: Key to European Usnea species. Bibliotheca Lichenologica 100: 419-462.

Tõrra T. \& Randlane T. 2007: The lichen genus Usnea (lichenized Ascomycetes, Parmeliaceae) in Estonia with a key to the species in the Baltic countries. Lichenologist 39: 415-438. 